Check for updates

Cite this: Chem. Sci., 2019, 10, 10586

๑ All publication charges for this article have been paid for by the Royal Society of Chemistry

Received 8th July 2019

Accepted 1st October 2019

DOI: $10.1039 / \mathrm{c} 9 \mathrm{sc} 03355 f$

rsc.li/chemical-science

\section{Hypoxia-activated NIR photosensitizer anchoring in the mitochondria for photodynamic therapy $\dagger$}

\author{
Feng $\mathrm{Xu}^{a}{ }^{a}$ Haidong $\mathrm{Li}^{a}{ }^{a}$ Qichao Yao, ${ }^{a}$ Haoying Ge, ${ }^{a}$ Jiangli Fan, (D) a Wen Sun, (D) a \\ Jingyun Wang (D ${ }^{b}$ and Xiaojun Peng (D) *ac
}

Photodynamic therapy is considered as a promising treatment for cancer, but still faces several challenges. The hypoxic environment in solid tumors, imprecise tumor recognition and the lack of selectivity between normal and cancer cells extremely hinder the applications of photodynamic therapy in clinics. Moreover, the "always on" property of photosensitizers also increases the toxicity to normal tissues when exposed to light irradiation. In this study, a hypoxia-activated NIR photosensitizer ICy-N was synthesized and successfully applied for in vivo cancer treatment. ICy-N is in the inactivated state with low fluorescence whereas its NIR emission ( $\lambda_{\mathrm{em}}=716 \mathrm{~nm}$ ) was induced via reduction caused by nitroreductase at the tumor site. In addition, the reduced product $\mathrm{ICy}-\mathrm{OH}$ was specially located in the mitochondria and demonstrated a high singlet oxygen production under $660 \mathrm{~nm}$ light irradiation, which efficiently induced cell apoptosis $\left(\mathrm{IC}_{50}=0.63 \mu \mathrm{M}\right)$. The in vivo studies carried out in Balb/c mice indicated that ICy- $\mathrm{N}$ was suitable for precise tumor hypoxia imaging and can work as an efficient photosensitizer for restraining tumor growth through the PDT process.

\section{Introduction}

In recent decades, cancer has gradually become the major cause of death in both developed and less developed countries due to the growth and aging of the population and the incidence rate is increasing every year., ${ }^{1,2}$ Therefore, multiple treatments including radiotherapy, ${ }^{3,4}$ chemotherapy, ${ }^{5,6}$ immunotherapy, ${ }^{7,8}$ photothermal therapy (PTT), ${ }^{9,10}$ photodynamic therapy $(\mathrm{PDT})^{11-14}$ and so on have been developed for treating cancer. Among them, photodynamic therapy has attracted great interest due to its minimal invasiveness, negligible drug resistance, controllable treatment area selection and excellent therapeutic effects. ${ }^{15,16} \mathrm{~A}$ typical PDT process involves pretreatment with a photosensitizer and certain light irradiation on the tumour region which can activate the photosensitizer to produce reactive oxygen species (ROS) to damage cells..$^{17,18}$ Thus, the capacity of photosensitizers to produce ROS and tumour recognition remain the most important factors for maximum therapeutic effects and minimum side effects. Up to now, numerous efficient photosensitizers have been developed based on various fluorophores. ${ }^{19-22}$ But little effort has been devoted to

${ }^{a}$ State Key Laboratory of Fine Chemicals, Dalian University of Technology, 2 Linggong Road, Dalian 116024, P. R. China. E-mail: pengxj@dlut.edu.cn

${ }^{b}$ School of Life Science and Biotechnology, Dalian University of Technology, 2 Linggong Road, Dalian 116024, P. R. China

'Shenzhen Research Institute, Dalian University of Technology, Nanshan District, Shenzhen 518057, P. R. China

$\dagger$ Electronic supplementary information (ESI) available. See DOI: $10.1039 / \mathrm{c} 9 \mathrm{sc} 03355 \mathrm{f}$ enhancing the specificity of photosensitizers for tumour cells. Because the photosensitizer is always "on", ROS can be produced once it is exposed to light irradiation even in healthy cells, which consequently leads to undesired side effects. ${ }^{23}$ That's why patients should be kept out of light before being exposed to certain light irradiation. Hence, "stimuli-activatable" photosensitizers are urgently needed for precise photodynamic therapy and minimizing side effects.

The hypoxic environment is an important feature of tumours due to the insufficient supply of oxygen. Several methods have been reported for hypoxic tumour therapy, such as those based on thermoresponsive nanoplatforms, ${ }^{24}$ decomposition of the endogenous $\mathrm{H}_{2} \mathrm{O}_{2}$ system, ${ }^{25,26}$ electron transfer mediated upconversion nanoparticles (UCNPs), ${ }^{27}$ light-controlled drug release complex conjugates ${ }^{28}$ and so on. Nitroreductase (NTR) is a well-known specific enzyme overexpressed in solid tumours due to the hypoxic microenvironment which can effectively reduce the nitroaromatic to the corresponding arylamine by using reduced nicotinamide adenine dinucleotide (NADH) as an electron donor. ${ }^{29,30}$ Based on this reduction reaction, many nitroaromatic decorated probes have been developed for hypoxia imaging. ${ }^{31-35}$ Li's group proved that nitroreductase was over-expressed when the $\mathrm{O}_{2}$ concentration was below $10 \%$ and the para-nitro benzoate group was an ideal substrate for NTR with a fast response, high sensitivity and excellent selectivity because of the strong hydrogen-bonding interaction and spatial match ${ }^{31}$ Herein, a hypoxia-activated photosensitizer ICy-N was designed, not only for hypoxic imaging, but also for PDT of 
cancer cells under hypoxic conditions, by decorating hemicyanine dye $\mathbf{C y}-\mathbf{O H}$ with 4-nitrobenzyl bromide as the recognition site and the introduction of iodine into the indole ring was used to improve the intersystem crossing (ISC) process so as to increase singlet oxygen production. ${ }^{36}$ As depicted in Scheme 1, in normal tissue, ICy-N was in a fluorescence-off state because the Intramolecular Charge Transfer (ICT) process was restrained and the energy of the excited state was mainly released through the vibration relaxation pathway due to the vibration of the nitro group ${ }^{37}$ and the ISC process was blocked. As a result, the ability to produce singlet oxygen was restricted and the toxicity was minimized in normal cells. But in the tumour region, ICy-N will be reduced by NTR and consequently ICy-OH will be released, serving as an efficient type II PS for photodynamic therapy. When irradiated with $660 \mathrm{~nm}$ light, ICy-OH can be excited and reach the singlet state $\left(\mathrm{S}_{1}\right)$, which can be used for emitting fluorescence at 710 $\mathrm{nm}$. Meanwhile, some of the excited molecules will reach the triplet state $\left(\mathrm{T}_{1}\right)$ by the ISC process because of the "heavy atom effect" of the introduced iodine atom. Finally, the energy transfer from triplet states to the ground state of molecular oxygen results in the formation of singlet oxygen $\left({ }^{1} \mathrm{O}_{2}\right)$ which serves as a strong oxidant to induce cell apoptosis. Therefore, tumour recognition and precise PDT were simultaneously achieved.

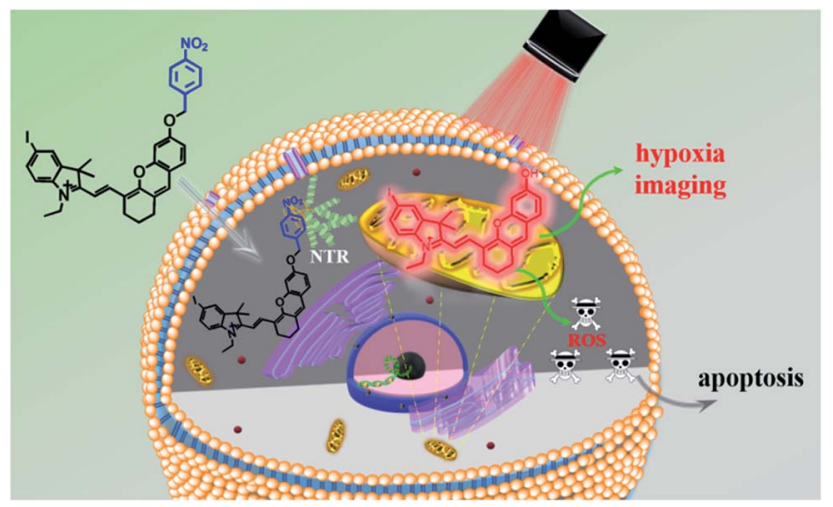

Scheme 1 Proposed strategy of ICy-N for hypoxia imaging and cancer therapy.

\section{Results and discussion}

Due to its unique properties including excellent photostability, controllable NIR emission and good water solubility, $\mathbf{C y}-\mathbf{O H}^{38}$ with iodine and 4-nitrobenzyl bromide substituents was selected for both precise tumour imaging and photodynamic therapy in this work. The water solubility and stability were characterized by transmission electron microscopy (TEM) and UV-vis spectroscopy. As shown in Fig. S1, $\dagger$ ICy-N showed slight aggregation in water and exhibited spherical morphology with a diameter of about $5 \mathrm{~nm}$. Meanwhile, the absorbance measured during $6 \mathrm{~h}$ changed scarcely which indicated that ICy$\mathbf{N}$ was stable and dispersed well in water solution. The recognition mechanism of the ICy-N response to nitroreductase is shown in Scheme 2. ICy-N was non-fluorescent in PBS buffer while its reduced product ICy-OH emitted strong fluorescence at $710 \mathrm{~nm}$, which was extremely important for tumour hypoxia imaging (Fig. 1a). Along with the change of fluorescence spectra, the maximum absorption peak of ICy-N red shifted from $575 \mathrm{~nm}$ to $655 \mathrm{~nm}$ (Fig. 1b). This is a favorable result for PDT because longer wavelengths have deeper penetration in tissues when exposed to light irradiation during a therapeutic process. In addition, the quenching of the excited state by the nitro group of ICy-N may also lead to lower triplet state production which consequently resulted in a lower singlet oxygen quantum yield $\left(\Phi_{\Delta}\right)$ in contrast to ICy-OH. To confirm this hypothesis, the ability of ICy-N and ICy-OH to produce singlet oxygen $\left({ }^{1} \mathrm{O}_{2}\right)$ was tested and compared by using 1,3diphenylisobenzofuran (DPBF) as the ${ }^{1} \mathrm{O}_{2}$ trapping agent and methylene blue (MB) as a reference. As seen in Fig. 1d, the absorbance of DPBF at $415 \mathrm{~nm}$ decreased dramatically in the presence of ICy-OH under $660 \mathrm{~nm}$ light irradiation, while ICy$\mathbf{N}$ only resulted in slight bleaching of DPBF under identical conditions (Fig. 1C). The singlet oxygen quantum yield $\left(\Phi_{\Delta}\right)$ was calculated to be $0.72 \%$ and $1.80 \%$ for ICy-N and ICy-OH respectively, suggesting that the reduced product ICy-OH displayed stronger ROS production capacity and thus may result in higher toxicity to cancer cells (Table $\mathrm{S} 1 \dagger$ ). What's more, the ${ }^{1} \mathrm{O}_{2}$ production of $\mathbf{I C y}-\mathbf{O H}$ was also proved by Singlet Oxygen Sensor Green (SOSG) and electron paramagnetic resonance (EPR) measurements (Fig. S5†), showing that ICy-

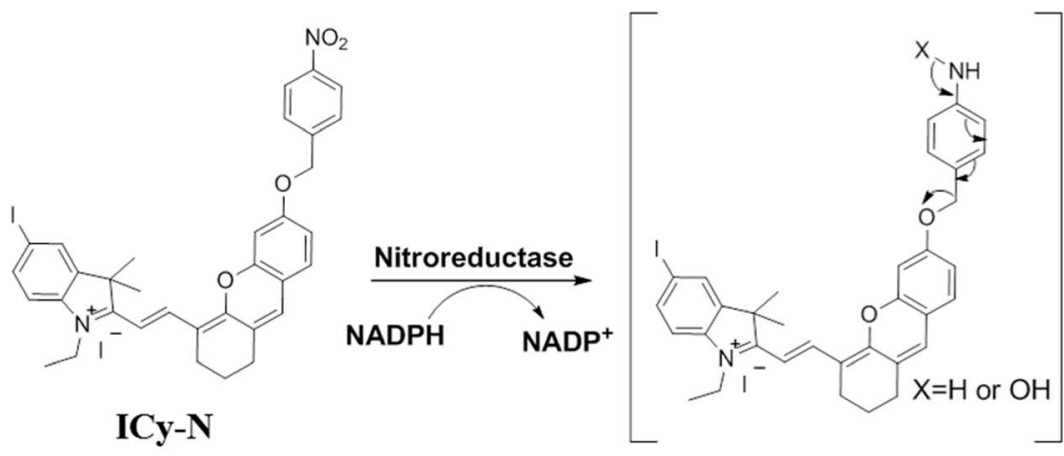

ICy-N

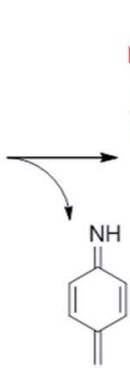

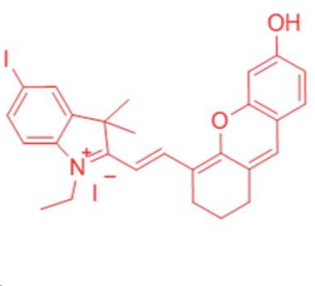

ICy-OH

Scheme 2 Recognition mechanism of ICy-N with NTR. 

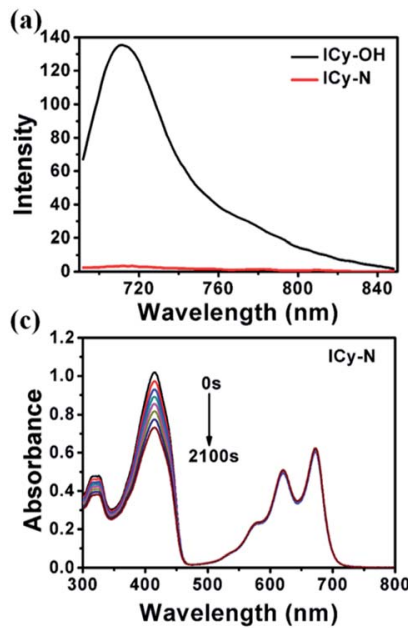

(b)

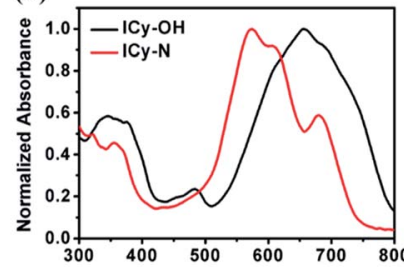

(d)

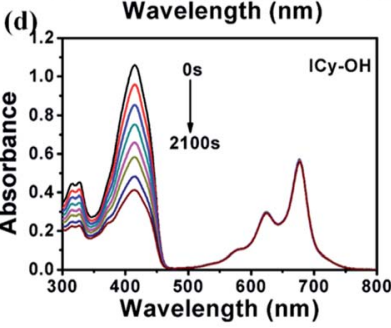

Fig. 1 (a) Fluorescence and (b) UV-vis spectra of ICy-N and ICy-OH in PBS buffer ( $\mathrm{pH}=7.4,10 \mathrm{mM})$. (c) Photodegradation curves of DPBF with ICy- $\mathrm{N}$ and (d) $\mathrm{ICy}-\mathrm{OH}$ under $660 \mathrm{~nm}$ light irradiation for different times $(0-2100 \mathrm{~s})$.

OH can serve as an efficient photosensitizer under $660 \mathrm{~nm}$ light irradiation.

To confirm the feasibility of this protocol, 4T1 cells were preincubated under hypoxia $\left(10 \%, 2 \%\right.$ and $\left.<1 \% \mathrm{O}_{2}\right)$ conditions for $8 \mathrm{~h}$ respectively to induce the overexpression of nitroreductase. Cells that were incubated under normoxic conditions were also taken as the control group. Then the cells were stained with ICy-N and incubated for another $60 \mathrm{~min}$ before imaging under a laser scanning confocal microscope. As expected, no obvious fluorescence was observed under normoxic conditions (Fig. 2a) due to the low expression of nitroreductase, whereas the hypoxia $\left(10 \%, 2 \%\right.$ or $\left.<1 \% \mathrm{O}_{2}\right)$ induced overexpression of nitroreductase gave rise to a significant red fluorescence signal. The result demonstrated that $\mathbf{I C y}-\mathbf{N}$ was reduced by nitroreductase, followed by releasing $\mathbf{I C y}-\mathbf{O H}$ with red fluorescence when excited with a $635 \mathrm{~nm}$ laser (as illustrated in Scheme 2). To further investigate the subcellular organelle localization of the reduced product, various commercial trackers and ICy-N (2.5 $\mu \mathrm{M})$ were applied to the cells that were pretreated under hypoxic conditions $\left(2 \% \mathrm{O}_{2}\right)$ for $60 \mathrm{~min}$ respectively (Fig. 2b). Apparently, a poor colocalization region fluorescence signal was observed between the reduced product and LysoTracker Green (a lysosomal tracker) or Hoechst 33342 (a nuclear tracker). In contrast, the red fluorescence overlapped well with the MitoTracker Green (a mitochondrial tracker), indicating that ICy-N can be triggered by NTR efficiently and finally gathered in the mitochondria. When MCF-7 cells were treated with carbonyl cyanide 3-chlorophenylhydrazone (CCCP, a membrane potential uncoupler) to induce the loss of mitochondria membrane potential, the fluorescence signal of ICy-N decreased dramatically, whereas, the fluorescence signal of MitoTracker Green FM (a mitochondrial probe whose uptake is independent of membrane potential) remained unchanged (Fig. S6†). This result can be attributed to the negative membrane potential $(-180 \mathrm{mV})$ of the mitochondria which facilitates the uptake of

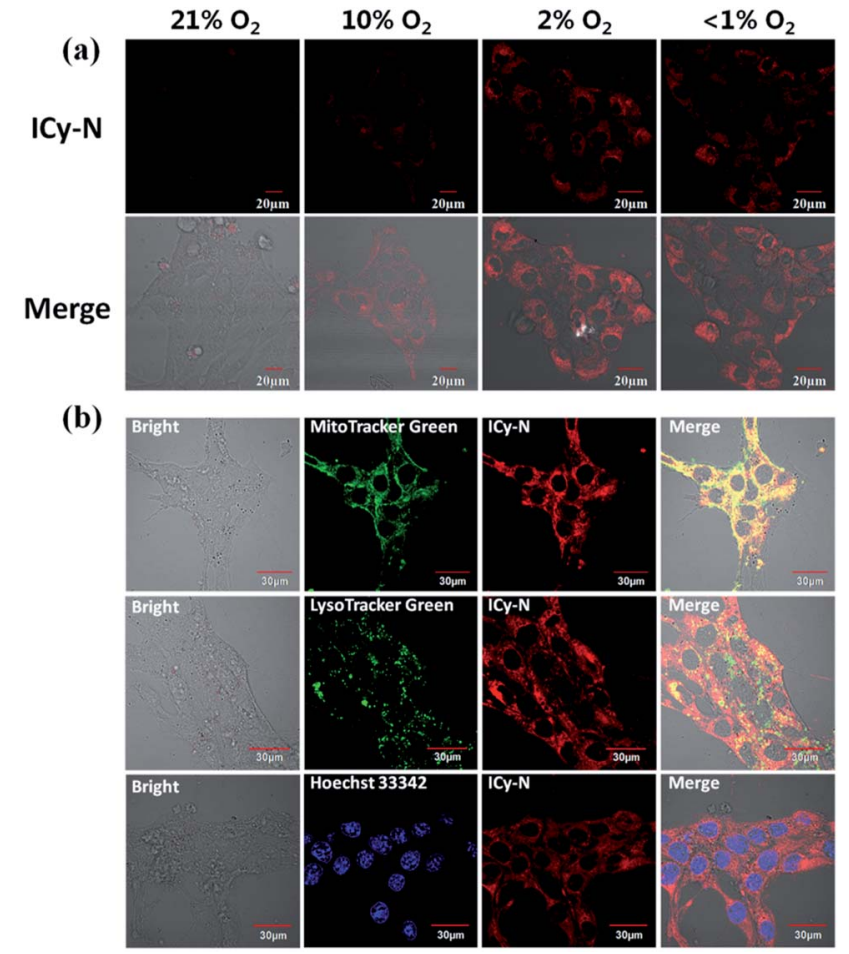

Fig. 2 (a) Confocal microscopy imaging of $2.5 \mu \mathrm{M} \mathrm{ICy}-\mathrm{N}$ in $4 \mathrm{~T} 1$ cells under different $\mathrm{O}_{2}$ concentrations. (b) Subcellular colocalization assays of ICy-N in 4T1 cells. The green channel of MitoTracker Green and LysoTracker Green was excited at $488 \mathrm{~nm}$ and collected at 500$550 \mathrm{~nm}$. The blue channel of Hoechst 33342 was excited at $405 \mathrm{~nm}$ and collected at $440-480 \mathrm{~nm}$.

molecules with positive charge. ${ }^{39-41}$ It is quite important for improving the PDT efficiency of photosensitizers because mitochondrial damage and the following release of cytochrome $\mathrm{C}$ to trigger apoptosis was considered to be the main pathway during the PDT process. ${ }^{42}$

Then, the PDT properties of the reduced product were studied with a $660 \mathrm{~nm}$ LED lamp. 4T1 cells were preincubated under hypoxic conditions $\left(10 \% \mathrm{O}_{2}, 5 \% \mathrm{CO}_{2}\right)$ for $8 \mathrm{~h}$ and treated with $2.5 \mu \mathrm{M}$ ICy-N for $60 \mathrm{~min}$, followed by exposure to $660 \mathrm{~nm}$ light (12 $\left.\mathrm{mW} \mathrm{cm}^{-2}\right)$ for $5 \mathrm{~min}$. After that, annexin V-FITC and PI (Propidium Iodide) were utilized for assessing cell apoptosis induced after the treatment. When apoptosis occurs, phosphatidylserine inside the cytomembrane will turn over to the outside which can be recognized by annexin $\mathrm{V}$ with high affinity and specificity. With the development of apoptosis, the permeability of the cytomembrane changes so that PI can enter the cells and combine with DNA to emit red fluorescence, whereas it is inaccessible in living cells. As shown in Fig. 3a, the fluorescence signal of FITC was detected in the cytomembrane in the ICy-N + Light group, indicating that apoptosis was induced. Strong red fluorescence in the cell nucleus in the PI channel can also be observed, which indicated cell death after PDT. This phenomenon was in accordance with the one treated with ICy-OH under the same conditions (Fig. S8†). In contrast, no fluorescence signal was observed from FITC and PI channels in Light and ICy-N groups, because the cells were still surviving 

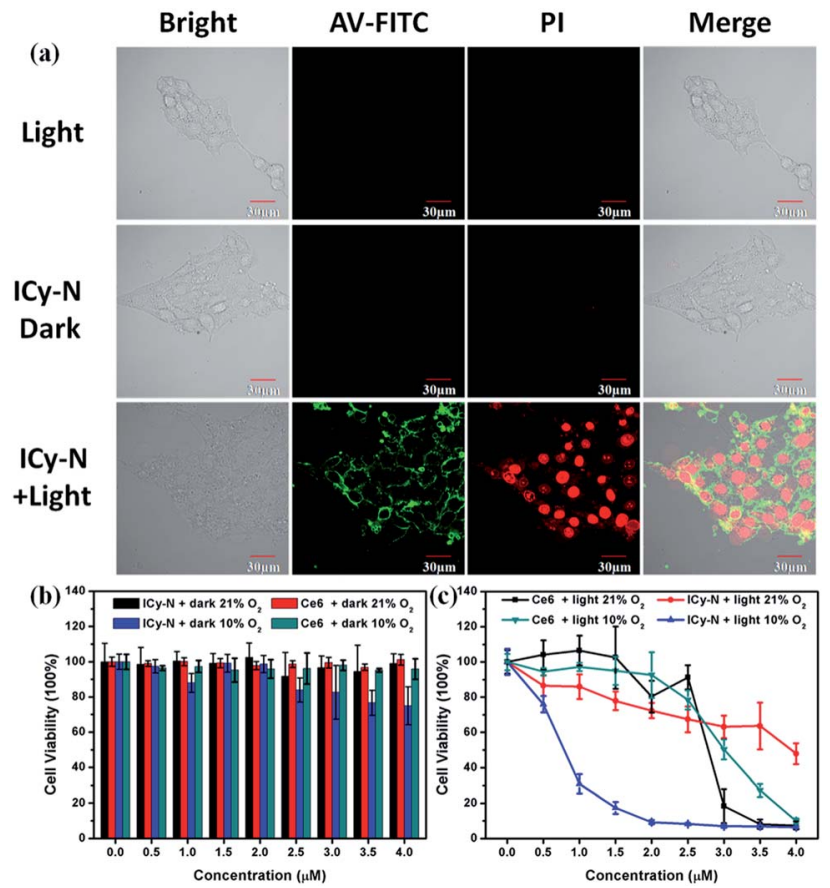

Fig. 3 (a) Confocal microscopy imaging of annexin V - FITC and PI stained $4 \mathrm{~T} 1$ cells after different treatments. The green channel of annexin V - FITC was excited at $488 \mathrm{~nm}$ and collected at 500-550 $\mathrm{nm}$; the red channel of PI was excited at $561 \mathrm{~nm}$ and collected at 590$640 \mathrm{~nm}$. Cytotoxicity of photosensitizers under dark conditions (b) and irradiation with $660 \mathrm{~nm}$ light (c) at various concentrations.

in these control groups. To get a better understanding of the cytotoxicity mechanism, the JC-1 assay was carried out in MCF-7 cells. As shown in Fig. S9, $\uparrow$ when MCF-7 cells were treated with $2.5 \mu \mathrm{M}$ ICy-N and irradiated with $660 \mathrm{~nm}$ light, the fluorescence signal of the red channel which belongs to the aggregation of JC-1 in the mitochondria decreased dramatically while the red fluorescence in the dark group was obvious, indicating mitochondrial damage. This result demonstrated that cell apoptosis was induced by mitochondrial dysfunction during the PDT process. All these results proved that the reduced product can work as an efficient photosensitizer and induce cell apoptosis under $660 \mathrm{~nm}$ light irradiation.

To further investigate the cytotoxicity of ICy-N and the reduced product ICy-OH, the MTT assay was carried out (Fig. 3b and c). Negligible cytotoxicity was observed in the ICy-N treated group under $21 \% \mathrm{O}_{2}$ and the viability of MCF-7 cells was still above $98 \%$ at a concentration of $4 \mu \mathrm{M}$ under dark conditions. However, considerable damage was found after $12 \mathrm{~h}$ incubation in the $10 \% \mathrm{O}_{2}$ group which was caused by the reduced product ICy-OH. The higher cytotoxicity of ICy-OH was beneficial for tumour therapy because only in tumour tissues can ICy-N be reduced to $\mathbf{I C y}-\mathbf{O H}$. Next, the PDT effect was studied under 660 $\mathrm{nm}$ light irradiation $\left(12 \mathrm{~mW} \mathrm{~cm}^{-2}\right)$ after incubation with ICy-N for $60 \mathrm{~min}$ under $21 \%$ and $10 \% \mathrm{O}_{2}$ conditions, respectively. As shown in Fig. 3c, the photo-induced cytotoxicity of ICy-N was improved with increasing ICy-N concentration. But the PDT was still inefficient in the $21 \% \mathrm{O}_{2}$ group in contrast to that treated with $10 \% \mathrm{O}_{2}$. The cell viability decreased rapidly when the concentration of ICy-N increased under $10 \% \mathrm{O}_{2}$ conditions and only $20 \%$ cells survived at a concentration of $1.5 \mu \mathrm{M}$, whereas, $80 \%$ cells were still alive in the $21 \% \mathrm{O}_{2}$ treated group at the same concentration. This result was consistent with the hypothesis we proposed that a higher singlet oxygen quantum yield of ICy-OH can lead to stronger cytotoxicity so that the side effects in normal tissues can be minimized during the PDT process.

To have a better understanding of the PDT efficiency of ICy$\mathbf{N}$, a clinical photosensitizer $\mathbf{C e} 6$ was used as a contrast. Similar cell viability was observed between ICy-N and Ce6 under dark conditions which further verified the good biocompatibility of ICy-N. However, quite different PDT efficiency was found in the light treated groups. Ce6 seems nontoxic at low concentrations $(0-1.5 \mu \mathrm{M})$ while strong cytotoxicity was found in the group treated with ICy-N under $10 \% \quad \mathrm{O}_{2}$ conditions. When the concentration increased to $3 \mu \mathrm{M}$, comparative cell viability was observed and the $\mathrm{IC}_{50}$ values of $\mathbf{I C y}-\mathbf{N}$ under $10 \% \mathrm{O}_{2}$ conditions and Ce6 were determined to be $0.63 \mu \mathrm{M}$ and $2.79 \mu \mathrm{M}$ respectively, indicating that ICy-N demonstrates a better PDT efficiency than $\mathbf{C e} 6$ under identical conditions.

To get more proof of the photo-induced cytotoxicity of the reduced product $\mathbf{I C y}-\mathbf{O H}$, DCFH-DA was used for tracking the ROS production during the PDT process. Striking contrast was found that strong fluorescence of DCF was observed after irradiation with $660 \mathrm{~nm}$ light, whereas the signal was low in the dark indicating that ICy-OH can work as an efficient photosensitizer and produce ROS under irradiation (Fig. S7 $\dagger$ ). In addition, the ROS induced apoptosis was visible even in the bright image (Fig. S10 $\dagger$ ). After being irradiated with a $635 \mathrm{~nm}$ laser for $1 \mathrm{~min}$, obvious vesicles were observed with the extension of incubation time indicating the development of apoptosis. In contrast, when the cells without treatment with ICy-OH were exposed to the same laser irradiation, no morphological change was found. Then, the cell death was further proved by flow cytometry statistically. As seen in Fig. S11, $\dagger$ the PI signal in the ICy-OH treated group was negative. After irradiation with $660 \mathrm{~nm}$ light, a positive signal was observed, showing the death of MCF-7 cells.

All these results indicated that ICy-N was in a fluorescenceoff state and had negligible cytotoxicity under dark conditions and low PDT efficiency without reduction by NTR (in normal tissues). But, it can be turned on under hypoxic conditions by NTR (in tumour tissues) and the reduced product ICy-OH showed higher singlet oxygen production. Thus, ICy-OH is an efficient photosensitizer and is promising for PDT under 660 nm light irradiation.

Inspired by the excellent performance of ICy-N during the PDT process in vitro, an in vivo study was carried out in 4T1 tumour bearing Balb/c mice. Firstly, Balb/c mice were implanted with a 4T1 tumour subcutaneously at the left armpit and then divided into four groups (Control, Light, ICy-N, and ICy-N + Light) when the tumour volume reached $200 \mathrm{~mm}^{3}$. The feasibility of ICy-N as an NIR fluorescent probe for hypoxia imaging was tested by intratumoral injection of ICy-N in PBS buffer in 4T1 tumour bearing Balb/c mice. As depicted in Fig. 4, an obvious fluorescence signal (680-720 nm) was observed in 

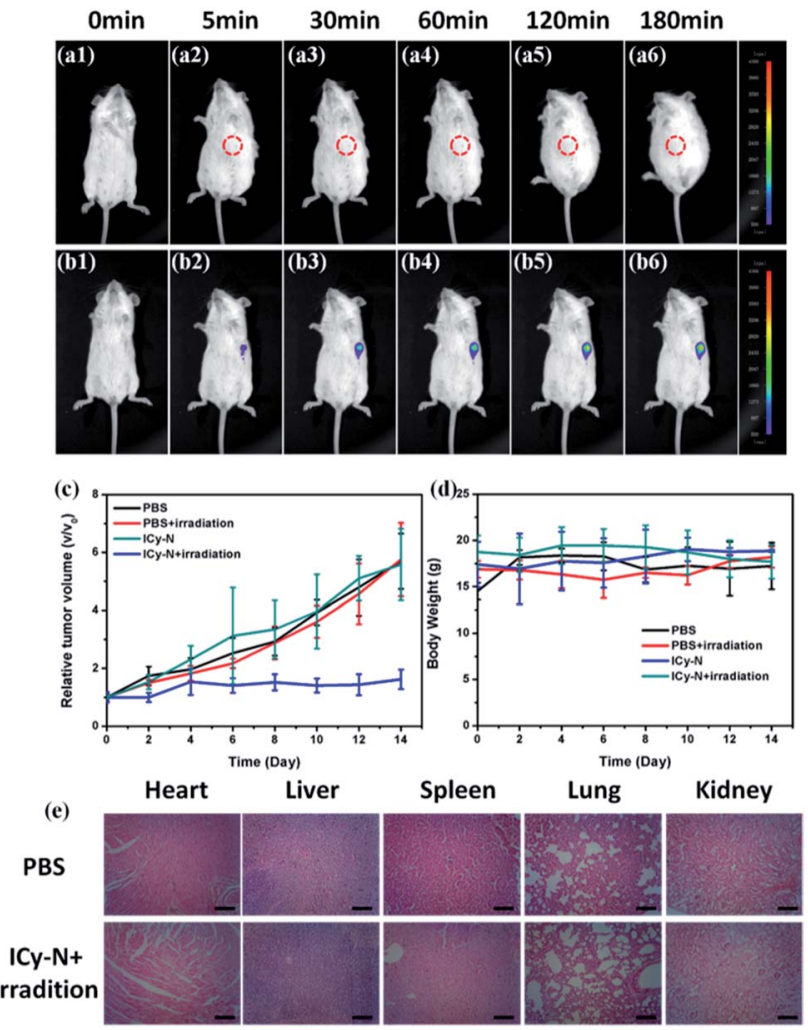

Fig. 4 In vivo fluorescence imaging of nitroreductase in Balb/c mice. (a1-a6) PBS (100 $\mu \mathrm{L})$ was injected subcutaneously and (b1-b6) ICy-N $(100 \mu \mathrm{L}, 50 \mu \mathrm{M}$ in PBS) was injected intratumorally and observed with excitation at $660 \mathrm{~nm}$ and emission at $680-720 \mathrm{~nm}$. The red circle in (a2-a6) represents the injected region. (c) Relative tumor volume and (d) body weight of mice after different treatments. (e) H\&E staining of organs from the PBS group and PDT group after 14 days of treatment. Scale bar: $50 \mu \mathrm{m}$.

the tumour region (b1-b6) due to the overexpression of NTR under hypoxic conditions of tumours. As time went by, the intensity gradually increased and remained unchanged after $180 \mathrm{~min}$, suggesting that the reduction of ICy-N by NTR was finished after $3 \mathrm{~h}$, which was selected as the preincubation time before exposure to $660 \mathrm{~nm}$ light during the PDT process. As a comparison, Balb/c mice without tumour were injected with PBS subcutaneously and imaged at the same time period. No fluorescence signal was captured in spite of the extension of incubation time indicating that ICy-N was in a fluorescence-off state in normal tissues and can only be turned on by NTR specifically and the NIR fluorescence emission was suitable for bioimaging in vivo. Further, the PDT effect was assessed through the tumour volume growth and body weight of mice which were collected every two days (Fig. $4 \mathrm{c}$ and d). Distinctly, the tumour volume increased quickly in the PBS treated group whether the mice were irradiated with $660 \mathrm{~nm}$ light or not. Besides, the group treated with ICy-N under dark conditions showed a similar tumour growth rate to the control group indicating the low cytotoxicity of ICy-N under dark conditions. In contrast, the PDT group that was irradiated with a $660 \mathrm{~nm}$ lamp $\left(100 \mathrm{~mW} \mathrm{~cm}^{-2}\right)$ for $20 \mathrm{~min}$ after pretreatment with ICy-N for $3 \mathrm{~h}$ demonstrated evident suppression of tumour growth.
The tumour volume remained almost unchanged for 14 days while other groups exhibited above 5-fold increase. The anticancer capability in vivo was as good as Ce6 (Fig. S12†). More importantly, scars were observed at the tumour surface in the PDT group, demonstrating that severe damage was caused in tumours through the PDT treatment (Fig. S13 $\dagger$ ).

The body weight of mice changed scarcely both in PDT and control groups indicating that no obvious injury was induced in mice during the treatment. To further prove this, the mice were euthanized after 14 days and dissected to get the organs of the four groups, which were made into paraffin slices and stained with hematoxylin and eosin (H\&E). As seen in Fig. 4e and S9, $\dagger$ the organs in the PDT group didn't show any difference compared with the PBS treated one. Additionally, no physiological morphology abnormalities or histopathological lesions were observed, indicating low toxicity of ICy-N to normal tissues. All these results confirmed that ICy-N was suitable for precise tumour imaging and served as an efficient photosensitizer to restrain tumour growth under light irradiation.

\section{Conclusions}

In summary, an iodine substituted NIR hemicyanine dye ICy-N was synthesized and successfully applied for tumour hypoxia imaging and photodynamic therapy in this study. ICy-N is in a fluorescence-off state and has poor singlet oxygen quantum yield due to the vibration of the nitro group in normal tissues, whereas it can be reduced by the over-expressed nitroreductase in the tumour region. The reduced product ICy-OH displayed a strong fluorescence emission at $710 \mathrm{~nm}$ which is suitable for in vivo bioimaging. More importantly, the improved singlet oxygen production of ICy-OH makes it an efficient photosensitizer to induce cell apoptosis under $660 \mathrm{~nm}$ light irradiation. The in vivo antitumor experiment further confirms that ICy-N can serve as a promising NIR photosensitizer both for precise tumour hypoxia imaging and photodynamic therapy after the activation of nitroreductase. Overall, this work provides a novel strategy for establishment of an "activatable" photosensitizer for precise imaging and therapy.

\section{Experimental section}

\section{Materials and instruments}

All reagents and solvents used were of reagent grade and were obtained from commercial suppliers. Flash column chromatography was performed with silica gel (200-300 mesh) and dichloromethane/methanol or petroleum ether/ethyl acetate was used as eluent. ${ }^{1} \mathrm{H}$ NMR and ${ }^{13} \mathrm{C}$ NMR spectra were obtained using a BrukerAvance II $400 \mathrm{MHz}$ spectrometer. Chemical shift $(\delta)$ was reported as ppm in $\mathrm{CDCl}_{3}$ or DMSO- $d_{6}$ with TMS as the internal standard. The mass spectrum was recorded on LTQ Orbitrap XL MS instruments. ICy-OH and ICy-N were dissolved in DMSO at a concentration of $1 \mathrm{mM}$ respectively as the stock solution and stored at $-20{ }^{\circ} \mathrm{C}$ for further use. UV-vis spectra and fluorescent spectra were achieved from an Agilent Technologies CARY 60 UV-vis spectrophotometer (serial no. MY1523004) and Varian CARY Eclipse fluorescence 
spectrophotometer (serial no. MY15210003) respectively. The excitation and emission slit widths were adjusted to obtain the fluorescence intensity in the appropriate range. Cell imaging was performed on Olympus FV1000 and FV3000 confocal microscopes (Olympus, Japan). Mitotracker Green, Lysotracker Green and Hoechst 33342 were purchased from Life Technologies Co. (USA). Reactive oxygen species detection kit DCFH-DA (2,7-dichlorodihydrofluorescein diacetate) and annexin V-FITC and PI apoptosis kits were purchased from Nanjing KeyGen Biotech. Co. Ltd. (China).

\section{Determination of singlet oxygen quantum yield $\left(\Phi_{\Delta}\right)$}

The singlet oxygen quantum yield was determined by the reported method. ${ }^{43}$ Briefly, Methylene Blue (MB) was used as the reference and 1,3-diphenylisobenzofuran (DPBF) was used as the singlet oxygen trapper. Firstly, the concentration of DPBF in $3 \mathrm{~mL}$ DCM was modified to adjust the absorbance at $415 \mathrm{~nm}$ close to 1.0. Then, appropriate concentrations of $\mathrm{MB}$ and samples were added respectively to make sure that the absorbance of the mixture at $660 \mathrm{~nm}$ was between 0.2 and 0.4. After that, the mixture solutions were exposed to $660 \mathrm{~nm}$ light irradiation and the absorption spectrum was recorded with a UV-vis spectrophotometer. At last, the singlet oxygen quantum yield was calculated with the following equation:

$$
\Phi_{\Delta}=\Phi_{\mathrm{MB}} \times\left(k_{(\mathrm{ps})} \times F_{(\mathrm{MB})}\right) /\left(k_{(\mathrm{MB})} \times F_{(\mathrm{PS})}\right)
$$

$\Phi_{\Delta}$ represents the singlet oxygen quantum yield of the tested photosensitizer; $\Phi_{\mathrm{MB}}$ represents the singlet oxygen quantum yield of MB and the value is 0.57 in DCM; PS represents the tested photosensitizer ICy-N or ICy-OH; $k$ represents the slope of the decrease of the absorbance at $415 \mathrm{~nm}$ of DPBF with the addition of irradiation time; $F$ is the correction factor which is calculated by the following equation:

$$
F=1-10^{-\mathrm{OD}}
$$

OD represents the absorbance of the mixture at $660 \mathrm{~nm}$.

\section{Cell incubation}

Breast cancer cells (MCF-7 cells and 4T1 cells) were purchased from the Institute of Basic Medical Sciences (IBMS) of the Chinese Academy of Medical Sciences and cultured with Dulbecco's modified Eagle's medium (DMEM, Invitrogen) containing $10 \%$ fetal bovine serum (Invitrogen) and 1\% antibiotics (penicillin/streptomycin, $100 \mathrm{U} \mathrm{mL}^{-1}$ ) in an atmosphere of $\mathrm{CO}_{2} /$ air $=5 \% / 95 \%$ at $37{ }^{\circ} \mathrm{C}$.

\section{Endogenous nitroreductase imaging in 4T1 cells}

For hypoxia incubation, 4T1 cells were seeded in confocal culture dishes at an approximate concentration of $2 \times 10^{4}$ cells per $\mathrm{mL}$ and incubated in a cell incubator under normal conditions for $12 \mathrm{~h}$ and then the dishes were moved to a sealed box filled with $2 \%$ (or $10 \%$ ) $\mathrm{O}_{2}$ and $5 \% \mathrm{CO}_{2}$ for $8 \mathrm{~h}$ to induce the overexpression of NTR. As for lower $\mathrm{O}_{2}$ concentration, AnaeroPouch was placed with cell dishes to remove residual $\mathrm{O}_{2}$. Then, the $4 \mathrm{~T} 1$ cells were incubated with $2.5 \mu \mathrm{M}$ ICy-N at $37{ }^{\circ} \mathrm{C}$ for 60 min and washed with PBS 3 times before scanning under the confocal microscope. Finally, photosensitizers were excited with a $635 \mathrm{~nm}$ laser and the signal of the fluorescence channel at $700-750 \mathrm{~nm}$ was gathered with a $60 \times$ objective lens $(N=3)$.

\section{Apoptosis assessment with annexin V-FITC \& PI under a confocal microscope}

4T1 cells were pre-incubated under hypoxic conditions as mentioned before and incubated with $2.5 \mu \mathrm{M}$ ICy-N for $60 \mathrm{~min}$. Then, the cells were washed with DMEM (containing 10\% FBS) 3 times and irradiated with $660 \mathrm{~nm}$ light for $10 \mathrm{~min}$ and incubated for another $30 \mathrm{~min}$ at $37{ }^{\circ} \mathrm{C}$ to induce apoptosis. After that, DMEM culture medium was replaced with $1 \times$ binding buffer and $5 \mu \mathrm{L}$ annexin $\mathrm{V}$ and $5 \mu \mathrm{L}$ PI were added and mixed slightly. After $30 \mathrm{~min}$ incubation at $37^{\circ} \mathrm{C}$, the cells were imaged under an Olympus FV-1000. The green channel (annexin V) was excited at $488 \mathrm{~nm}$ and the fluorescence signal at 500-550 nm was collected. The red channel (PI) was excited at $561 \mathrm{~nm}$ and the fluorescence signal at 590-640 nm was collected $(N=3)$.

\section{Detection of cellular ROS generation within DCFH-DA}

MCF-7 cells were seeded at confocal culture dishes at a density of $5 \times 10^{4}$ and pre-incubated under hypoxic conditions. Then, various concentrations of ICy-N and $10 \mu \mathrm{M}$ DCFH-DA were added and incubated for $60 \mathrm{~min}$. Then, the cells were washed with PBS 3 times and irradiated with a $635 \mathrm{~nm}$ laser for $2 \mathrm{~min}$ and scanned under a confocal microscope at $488 \mathrm{~nm}$ excitation, whereas, the fluorescence channel at 500-550 nm was collected $(N=3)$.

\section{Cytotoxicity assay}

The cytotoxicity in the presence or absence of light was evaluated by reducing MTT (3-(4,5)-dimethylthiazol-2-yl)-3,5-diphenyltetrazolium bromide) to formazan crystals with mitochondrial dehydrogenases. MCF-7 cells were seeded in a 96-well plate with a concentration of $1 \times 10^{5}$ cells per $\mathrm{mL}$ in $100 \mu \mathrm{L}$ DMEM medium (containing 10\% FBS). After $24 \mathrm{~h}$ attachment in a cell incubator, the cells were then treated with various concentrations of ICy-N, ICy-OH and Ce6 in $100 \mu \mathrm{L}$ medium for $60 \mathrm{~min}(N=6)$. Then the plate was irradiated with $660 \mathrm{~nm}$ light at an average optical density of $12 \mathrm{~mW} \mathrm{~cm}^{-2}$ for 10 min and then incubated in the cell incubator. As for the dark group, the cells were kept out of light with the other treatments unchanged. Cells cultured with free medium were used as control and six replicates were set for each group to eliminate contingency. After $12 \mathrm{~h}$ incubation, the medium was replaced with $100 \mu \mathrm{L}$ MTT ( $5 \mathrm{mg} \mathrm{mL}^{-1}$ in DMEM) solution and cultured for another $4 \mathrm{~h}$ at $37^{\circ} \mathrm{C}$ in the cell incubator. Finally, the MTT solution was removed carefully and the formed crystals were dissolved in $100 \mu \mathrm{L}$ dimethyl sulfoxide (DMSO). The plate was then carefully shaken for $10 \mathrm{~min}$ and the absorbance was determined on a microplate reader (Thermo Fisher Scientific) at $570 \mathrm{~nm}$ and $630 \mathrm{~nm}$. The viability was expressed as a percent of the controlled one using the following equation: 


$$
\begin{aligned}
\text { Cell viability }(\%)= & \left(\text { ODdye }_{570}-\text { ODdye }_{630}\right) /\left(\text { ODcontrol }_{570}\right. \\
& \left.- \text { ODcontrol }_{630}\right) \times 100
\end{aligned}
$$

Visualization of nitroreductase and photodynamic therapy in the 4T1 tumor bearing mice model

All procedures were carried out in compliance with the Guide for the Care and Use of Laboratory Animal Resources and the National Research Council, and were approved by the Institutional Animal Care and Use Committee of the NIH. 4-5 week old $\mathrm{Balb} / \mathrm{c}$ mice were chosen for transplanting $4 \mathrm{~T} 1$ cells at a density of $5 \times 10^{6}$ under the armpit. When the tumour volume reached $200 \mathrm{~mm}^{3}$, the xenograft tumour mice were divided into 4 groups (Control, Light, ICy-N, and ICy-N + Light, $N=5$ ). The tumour volume was measured using a vernier caliper and calculated using the following equation:

$$
V=1 / 2 \times a \times b^{2}
$$

$V$ represents the tumour volume of mice, $a$ represents the longest diameter of the tumour region, and $b$ represents the diameter in the vertical direction according to $a$ of the tumour region.

As for nitroreductase imaging, the mice injected with $50 \mu \mathrm{M}$ ICy-N were narcotized and imaged with a NightOWL II LB983 small animal in vivo imaging system with $660 \mathrm{~nm}$ excitation and $700 \pm 20 \mathrm{~nm}$ emission filters. The light power for mice PDT was $100 \mathrm{~mW} \mathrm{~cm}^{-2}$.

\section{Synthesis of ICy-N}

The synthetic route to ICy-N is displayed in Scheme S1. $\dagger$

\section{Synthesis of compound 1((4-iodophenyl) hydrazine)}

$10 \mathrm{~g}$ 4-iodoaniline $(45.7 \mathrm{mmol})$ and $2 \mathrm{~mL}$ concentrated hydrochloric acid were dissolved in $40 \mathrm{~mL}$ water in a round-bottom flask and cooled to $0{ }^{\circ} \mathrm{C}$. Then, $3.5 \mathrm{~g}(50.7 \mathrm{mmol}) \mathrm{NaNO}_{2}$ in 10 $\mathrm{mL}$ water was added to the turbid solution dropwise and stirred for 1 hour at that temperature. The reaction mixture was then heated to room temperature and $17.3 \mathrm{~g} \mathrm{SnCl}_{2}(91.4 \mathrm{mmol})$ dissolved in $16 \mathrm{~mL}$ water and $4 \mathrm{~mL}$ concentrated hydrochloric acid was slowly added to the reaction mixture under continuous stirring. A light brown precipitate was obtained after 2 hour stirring and filtered under reduce pressure. After washing with water 3 times, the precipitate was dissolved in $200 \mathrm{~mL}$ saturated $\mathrm{NaOH}$ solution and extracted with ethyl acetate $(50 \mathrm{~mL} \times 3)$. The organic layer was then washed with $\mathrm{Na}_{2} \mathrm{~S}_{2} \mathrm{O}_{3}$ and saline and dried with anhydrous $\mathrm{Na}_{2} \mathrm{SO}_{4}$. Finally, the organic layer was evaporated to dryness to give compound $\mathbf{1}$ as a brown solid (8.4 g, 78.5\%). ${ }^{1} \mathrm{H}$ NMR (400 MHz, DMSO- $\left.d_{6}\right) \delta 7.35(\mathrm{~d}, J=8.8 \mathrm{~Hz}$, $2 \mathrm{H}), 6.89(\mathrm{~s}, 1 \mathrm{H}), 6.62$ (d, $J=8.8 \mathrm{~Hz}, 2 \mathrm{H}), 4.05$ (s, 2H). ESI-MS: $m$ / $z$ calcd for $\mathrm{C}_{6} \mathrm{H}_{8} \mathrm{IN}_{2}^{+}[\mathrm{M}+\mathrm{H}]^{+}: 234.97$, found: 234.97 .

\section{Synthesis of compound 2 (5-iodo-2,3,3-trimethyl-3H-indole)}

$5 \mathrm{~g}$ (4-iodophenyl) hydrazine $(21.3 \mathrm{mmol})$ and $3.7 \mathrm{~g}$ 3-methyl-2butanone $(42.6 \mathrm{mmol})$ were dissolved in $50 \mathrm{~mL}$ glacial acetic acid and heated to reflux for $4 \mathrm{~h}$ under continuous stirring. Then, the reaction mixture was poured into $200 \mathrm{~mL}$ water and extracted with ethyl acetate $(50 \mathrm{~mL} \times 3)$. The organic layer was washed with saline and dried with anhydrous $\mathrm{Na}_{2} \mathrm{SO}_{4}$. Finally, the organic layer was evaporated to dryness and the crude product was purified by silica gel column chromatography to obtain 2 as a deep red gummy liquid $(4.4 \mathrm{~g}, 72.4 \%) .{ }^{1} \mathrm{H}$ NMR $\left(400 \mathrm{MHz}, \mathrm{CDCl}_{3}\right) \delta 7.62(\mathrm{dd}, J=8.0,1.7 \mathrm{~Hz}, 1 \mathrm{H}), 7.59(\mathrm{~d}, J=1.3$ $\mathrm{Hz}, 1 \mathrm{H}), 7.29$ (d, $J=7.6 \mathrm{~Hz}, 1 \mathrm{H}), 2.25$ (s, 3H), 1.28 (s, 6H). ESIMS: $m / z$ calcd for $\mathrm{C}_{11} \mathrm{H}_{13} \mathrm{IN}^{+}[\mathrm{M}+\mathrm{H}]^{+}$: 286.01, found: 286.05.

\section{Synthesis of compound 3 (1-ethyl-5-iodo-2,3,3-trimethyl-3H- indol-1-ium iodide)}

$4.4 \mathrm{~g} 2$ (15.4 mmol) was dissolved in $20 \mathrm{~mL}$ toluene and heated to reflux. Then $7.2 \mathrm{~g}$ iodoethane $(46.2 \mathrm{mmol})$ in $5 \mathrm{~mL}$ toluene was added through a syringe in batches under continuous stirring. A pink precipitate was obtained after stirring for 6 hours and filtered under reduced pressure. The precipitate was washed with ethyl acetate 3 times and dried over a vacuum oven to afford 3 ( $4.7 \mathrm{~g}, 69.1 \%) .{ }^{1} \mathrm{H}$ NMR $\left(400 \mathrm{MHz}\right.$, DMSO- $\left.d_{6}\right) \delta 8.31(\mathrm{~s}$, $1 \mathrm{H}), 8.00(\mathrm{~d}, J=8.3 \mathrm{~Hz}, 1 \mathrm{H}), 7.78(\mathrm{~d}, J=8.2 \mathrm{~Hz}, 1 \mathrm{H}), 4.46(\mathrm{q}, J=$ $6.9 \mathrm{~Hz}, 2 \mathrm{H}), 2.80(\mathrm{~s}, 3 \mathrm{H}), 2.50(\mathrm{~s}, 6 \mathrm{H}), 1.41(\mathrm{t}, J=7.1 \mathrm{~Hz}, 3 \mathrm{H})$. ESIMS: $m / z$ calcd for $\mathrm{C}_{13} \mathrm{H}_{17} \mathrm{IN}^{+}[\mathrm{M}+\mathrm{H}]^{+}: 314.04$, found: 314.07 .

\section{Synthesis of compound 4 (2-bromocyclohex-1- enecarbaldehyde)}

12.4 $\mathrm{mL} \mathrm{PBr}_{3}$ was dissolved in $20 \mathrm{~mL} \mathrm{CHCl}_{3}$ and slowly added to a mixture of $11.2 \mathrm{~mL}$ anhydrous $\mathrm{DMF}$ and $30 \mathrm{~mL} \mathrm{CHCl}_{3}$ during a period of 1 hour at $0{ }^{\circ} \mathrm{C}$. Then $5 \mathrm{~mL}$ cyclohexanone (48.4 $\mathrm{mmol}$ ) was added dropwise at that temperature. After stirring for 1 hour, the mixture was heated to room temperature and stirred for another 12 hours. The mixture was poured into a 200 $\mathrm{mL}$ ice-water mixture and neutralized with a $\mathrm{NaHCO}_{3}$ solid until the $\mathrm{pH}$ is approximately 7 . The resulting solution was extracted with $\mathrm{CH}_{2} \mathrm{Cl}_{2}(50 \mathrm{~mL} \times 3)$ and dried over anhydrous $\mathrm{Na}_{2} \mathrm{SO}_{4}$. Finally, the organic layer was concentrated in vacuo to give an orange oil (6.8 g) which was used without further purification.

\section{Synthesis of compound 5}

$200 \mathrm{mg}$ 2-hydroxy-4-methoxybenzaldehyde (1.3 mmol) in $6 \mathrm{~mL}$ anhydrous DMF was added to $295 \mathrm{mg} 4(1.56 \mathrm{mmol})$ and $847 \mathrm{mg}$ $\mathrm{Cs}_{2} \mathrm{CO}_{3}(2.6 \mathrm{mmol})$. The mixture was stirred at $25{ }^{\circ} \mathrm{C}$ for 12 hours in a $\mathrm{N}_{2}$ atmosphere and extracted with water $(60 \mathrm{~mL})$ and ethyl acetate $(20 \mathrm{~mL} \times 3)$. After being dried over anhydrous $\mathrm{Na}_{2} \mathrm{SO}_{4}$, the organic layer was evaporated and the crude product was purified by silica gel column chromatography to obtain 5 as a yellow solid (125 mg, 39.7\%). ${ }^{1} \mathrm{H}$ NMR (400 $\mathrm{MHz}, \mathrm{CDCl}_{3}$ ) $\delta 10.31(\mathrm{~s}, 1 \mathrm{H}), 7.08(\mathrm{~d}, J=9.1 \mathrm{~Hz}, 1 \mathrm{H}), 6.69-6.63(\mathrm{~m}, 3 \mathrm{H}), 3.84$ $(\mathrm{s}, 3 \mathrm{H}), 2.57(\mathrm{t}, J=6.0 \mathrm{~Hz}, 2 \mathrm{H}), 2.44(\mathrm{t}, J=6.0 \mathrm{~Hz}, 2 \mathrm{H}), 1.74-1.68$ $(\mathrm{m}, 3 \mathrm{H})$.

\section{Synthesis of compound 6}

$242 \mathrm{mg} 5$ ( $1 \mathrm{mmol}), 441 \mathrm{mg} 3(1 \mathrm{mmol})$ and $0.2 \mathrm{~mL}$ piperidine were dissolved in $10 \mathrm{~mL}$ acetic anhydride and heated to $60{ }^{\circ} \mathrm{C}$ for 2 hours. The resulting blue mixture was poured into $100 \mathrm{~mL}$ 
water and extracted with $\mathrm{CH}_{2} \mathrm{Cl}_{2}(20 \mathrm{~mL} \times 3)$. The organic layer was dried over anhydrous $\mathrm{Na}_{2} \mathrm{SO}_{4}$ and evaporated under reduced pressure. The crude product was further purified by silica gel column chromatography to obtain 6 as a blue solid (432 mg, 64.9\%). ${ }^{1} \mathrm{H}$ NMR (400 MHz, DMSO- $\left.d_{6}\right) \delta 8.58(\mathrm{~d}, J=$ $14.8 \mathrm{~Hz}, 1 \mathrm{H}), 8.15(\mathrm{~d}, J=1.3 \mathrm{~Hz}, 1 \mathrm{H}), 7.88(\mathrm{dd}, J=8.3,1.4 \mathrm{~Hz}$, 1H), 7.62-7.56 (m, 2H), 7.48 (d, $J=8.4 \mathrm{~Hz}, 1 \mathrm{H}), 7.12$ (d, $J=2.2$ $\mathrm{Hz}, 1 \mathrm{H}), 7.04(\mathrm{dd}, J=8.7,2.3 \mathrm{~Hz}, 1 \mathrm{H}), 6.50$ (d, $J=14.9 \mathrm{~Hz}, 1 \mathrm{H})$, $4.38(\mathrm{q}, J=7.1 \mathrm{~Hz}, 2 \mathrm{H}), 3.93(\mathrm{~s}, 3 \mathrm{H}), 2.74(\mathrm{t}, J=5.8 \mathrm{~Hz} 2 \mathrm{H}), 2.69$ $(\mathrm{t}, J=5.8 \mathrm{~Hz}, 2 \mathrm{H}), 1.87-1.79(\mathrm{~m}, 2 \mathrm{H}), 1.75(\mathrm{~s}, 6 \mathrm{H}), 1.34(\mathrm{t}, J=7.1$ $\mathrm{Hz}, 3 \mathrm{H})$. ESI-MS: $m / z$ calcd for $\mathrm{C}_{28} \mathrm{H}_{29} \mathrm{INO}_{2}{ }^{+}[\mathrm{M}]^{+}: 538.12$, found: 538.28 .

\section{Synthesis of compound ICy-OH}

$1 \mathrm{~g} \mathrm{BBr}_{3}(4.0 \mathrm{mmol})$ in $10 \mathrm{~mL}$ anhydrous $\mathrm{CH}_{2} \mathrm{Cl}_{2}$ was added dropwise to $20 \mathrm{~mL}$ anhydrous $\mathrm{CH}_{2} \mathrm{Cl}_{2}$ solution containing 200 mg $6(0.3 \mathrm{mmol})$ at $0{ }^{\circ} \mathrm{C}$ with continuous stirring. After 1 hour stirring at that temperature, the solution was heated to room temperature and stirred for another 12 hours. Then the solution was poured into $100 \mathrm{~mL}$ water and extracted with $\mathrm{CH}_{2} \mathrm{Cl}_{2}(20 \mathrm{~mL}$ $\times 3$ ). The organic layer was dried over anhydrous $\mathrm{Na}_{2} \mathrm{SO}_{4}$ and evaporated to give a blue solid. The crude product was then purified by silica gel column chromatography to obtain ICy-OH as a blue solid (180 mg, 92.1\%). ${ }^{1} \mathrm{H}$ NMR (400 MHz, DMSO- $d_{6}$ ) $\delta 8.42(\mathrm{~d}, J=14.4 \mathrm{~Hz}, 1 \mathrm{H}), 8.08(\mathrm{~d}, J=1.3 \mathrm{~Hz}, 1 \mathrm{H}), 7.81(\mathrm{dd}, J=$ 8.3, $1.4 \mathrm{~Hz}, 1 \mathrm{H}), 7.62(\mathrm{~s}, 1 \mathrm{H}), 7.48(\mathrm{~d}, J=9.2 \mathrm{~Hz}, 1 \mathrm{H}), 7.34(\mathrm{~d}, J=$ $8.4 \mathrm{~Hz}, 1 \mathrm{H}), 6.84-6.78(\mathrm{~m}, 2 \mathrm{H}), 6.31$ (d, $J=14.5 \mathrm{~Hz}, 1 \mathrm{H}), 4.27$ (q, $J=7.0 \mathrm{~Hz}, 2 \mathrm{H}), 2.71(\mathrm{t}, J=5.8 \mathrm{~Hz}, 2 \mathrm{H}), 2.67(\mathrm{t}, J=5.8 \mathrm{~Hz}, 2 \mathrm{H})$, 1.85-1.78 (m, 2H), $1.71(\mathrm{~s}, 6 \mathrm{H}), 1.30$ (t, $J=7.1 \mathrm{~Hz}, 3 \mathrm{H})$. ESI-MS: $m / z$ calcd for $\mathrm{C}_{27} \mathrm{H}_{27} \mathrm{INO}_{2}^{+}[\mathrm{M}]^{+}: 524.11$, found: 524.23 .

\section{Synthesis of ICy-N}

$150 \mathrm{mg}$ ICy-OH (0.23 mmol), $60 \mathrm{mg}$ 1-(bromomethyl)-4-nitrobenzene and $95 \mathrm{mg} \mathrm{K}_{2} \mathrm{CO}_{3}(0.69 \mathrm{mmol})$ were dissolved in $10 \mathrm{~mL}$ DMF. The mixture was heated to $60{ }^{\circ} \mathrm{C}$ under a $\mathrm{N}_{2}$ atmosphere and monitored by TLC. When the reaction was completed, the mixture was washed with $60 \mathrm{~mL}$ water and extracted with $\mathrm{CH}_{2} \mathrm{Cl}_{2}(20 \mathrm{~mL} \times 3)$. The organic layer was dried over dried over anhydrous $\mathrm{Na}_{2} \mathrm{SO}_{4}$ and evaporated in vacuo. The crude product was then purified by silica gel column chromatography to obtain ICy-N as a blue solid (86 mg, 47.6\%). ${ }^{1} \mathrm{H}$ NMR $(400 \mathrm{MHz}$, DMSO- $\left.d_{6}\right) \delta 8.55(\mathrm{~d}, J=14.8 \mathrm{~Hz}, 1 \mathrm{H}), 8.32(\mathrm{~d}, J=8.5 \mathrm{~Hz}, 2 \mathrm{H})$, $8.18(\mathrm{~s}, 1 \mathrm{H}), 7.89(\mathrm{~d}, J=8.4 \mathrm{~Hz}, 1 \mathrm{H}), 7.80(\mathrm{~d}, J=8.6 \mathrm{~Hz}, 2 \mathrm{H}), 7.60$ $(\mathrm{d}, J=8.6 \mathrm{~Hz}, 1 \mathrm{H}), 7.56(\mathrm{~s}, 1 \mathrm{H}), 7.51(\mathrm{~d}, J=8.5 \mathrm{~Hz}, 1 \mathrm{H}), 7.21(\mathrm{~s}$, $1 \mathrm{H}), 7.13(\mathrm{~d}, J=8.8 \mathrm{~Hz}, 1 \mathrm{H}), 6.52(\mathrm{~d}, J=15.0 \mathrm{~Hz}, 1 \mathrm{H}), 5.49$ (s, $2 \mathrm{H}), 4.40(\mathrm{q}, J=7.2 \mathrm{~Hz}, 2 \mathrm{H}), 2.75-2.65(\mathrm{~m}, 4 \mathrm{H}), 1.87-1.77(\mathrm{~m}$, $2 \mathrm{H}), 1.74(\mathrm{~s}, 6 \mathrm{H}), 1.33(\mathrm{t}, J=7.0 \mathrm{~Hz}, 3 \mathrm{H}) .{ }^{13} \mathrm{C}$ NMR $(100 \mathrm{MHz}$, DMSO- $\left.d_{6}\right) \delta 176.68,161.50,161.30,154.22,147.65,145.52$, $144.87,144.65,141.39,137.98,134.09,131.97,129.58,129.05$, $127.79,124.22,116.39,115.54,114.97,114.14,104.54,102.62$, $92.90,69.37,50.85,45.71,28.89,27.72,24.15,20.36,13.03$. ESIMS: $m / z$ calcd for $\mathrm{C}_{34} \mathrm{H}_{32} \mathrm{IN}_{2} \mathrm{O}_{4}^{+}[\mathrm{M}]^{+}: 659.1407$, found: 659.1405 .

\section{Conflicts of interest}

The authors declare no competing financial interests.

\section{Acknowledgements}

This work was supported by the National Science Foundation of China (project 21421005, 21576037 and U1608222).

\section{Notes and references}

1 L. A. Torre, F. Bray, R. L. Siegel, J. Ferlay, J. Lortet-Tieulent and A. Jemal, Ca-Cancer J. Clin., 2015, 65, 87.

2 W. Chen, R. Zheng, P. D. Baade, S. Zhang, H. Zeng, F. Bray, A. Jemal, X. Q. Yu and J. He, Ca-Cancer J. Clin., 2016, 66, 115. 3 J. Du, Z. Gu, L. Yan, Y. Yong, X. Yi, X. Zhang, J. Liu, R. Wu, C. Ge, C. Chen and Y. Zhao, Adv. Mater., 2017, 29, 1701268.

4 N. Ma, F.-G. Wu, X. Zhang, Y.-W. Jiang, H.-R. Jia, H.-Y. Wang, Y.-H. Li, P. Liu, N. Gu and Z. Chen, ACS Appl. Mater. Interfaces, 2017, 9, 13037.

5 S. R. Chowdhury, S. Mukherjee, S. Das, C. R. Patra and P. K. Iyer, Chem. Sci., 2017, 8, 7566.

6 M. Xiao, W. Sun, J. Fan, J. Cao, Y. Li, K. Shao, M. Li, X. Li, Y. Kang, W. Zhang, S. Long, J. Du and X. Peng, Adv. Funct. Mater., 2018, 28, 1805128.

7 G. Lan, K. Ni, Z. Xu, S. S. Veroneau, Y. Song and W. Lin, J. Am. Chem. Soc., 2018, 140, 5670.

8 S. L. Topalian, F. S. Hodi, J. R. Brahmer, S. N. Gettinger, D. C. Smith, D. F. McDermott, J. D. Powderly, R. D. Carvajal, J. A. Sosman, M. B. Atkins, P. D. Leming, D. R. Spigel, S. J. Antonia, L. Horn, C. G. Drake, D. M. Pardoll, L. Chen, W. H. Sharfman, R. A. Anders, J. M. Taube, T. L. McMiller, H. Xu, A. J. Korman, M. JureKunkel, S. Agrawal, D. McDonald, G. D. Kollia, A. Gupta, J. M. Wigginton and M. Sznol, N. Engl. J. Med., 2012, 366, 2443.

9 Z. Zhou, Y. Yan, L. Wang, Q. Zhang and Y. Cheng, Biomaterials, 2019, 203, 63.

10 J. Gao, M. Sanchez-Purra, H. Huang, S. Wang, Y. Chen, X. Yu, Q. Luo, K. Hamad-Schifferli and S. Liu, Sci. China: Chem., 2017, 60, 1219.

11 M. Li, T. Xiong, J. Du, R. Tian, M. Xiao, L. Guo, S. Long, J. Fan, W. Sun, K. Shao, X. Song, J. W. Foley and X. Peng, J. Am. Chem. Soc., 2019, 141, 2695.

12 L. Huang, Z. Li, Y. Zhao, Y. Zhang, S. Wu, J. Zhao and G. Han, J. Am. Chem. Soc., 2016, 138, 14586.

13 J. P. Celli, B. Q. Spring, I. Rizvi, C. L. Evans, K. S. Samkoe, S. Verma, B. W. Pogue and T. Hasan, Chem. Rev., 2010, 110, 2795.

14 W. Chen, Y. Wang, M. Qin, X. Zhang, Z. Zhang, X. Sun and Z. Gu, ACS Nano, 2018, 12, 5995.

15 D. E. J. G. J. Dolmans, D. Fukumura and R. K. Jain, Nat. Rev. Cancer, 2003, 3, 380.

16 Z. Li, J. Wang, J. Chen, W. Lei, X. Wang and B. Zhang, Sci. China: Chem., 2010, 53, 1994.

17 S. Kwiatkowski, B. Knap, D. Przystupski, J. Saczko, E. Kędzierska, K. Knap-Czop, J. Kotlińska, O. Michel, K. Kotowski and J. Kulbacka, Biomed. Pharmacother., 2018, 106, 1098.

18 M. Li, S. Long, Y. Kang, L. Guo, J. Wang, J. Fan, J. Du and X. Peng, J. Am. Chem. Soc., 2018, 140, 15820. 
19 J. C. Kennedy and R. H. Pottier, J. Photochem. Photobiol., B, 1992, 14, 275.

20 K. Y. Choi, G. Liu, S. Lee and X. Chen, Nanoscale, 2012, 4, 330.

21 J. Zhang, C. Jiang, J. P. Figueiró Longo, R. B. Azevedo, H. Zhang and L. A. Muehlmann, Acta Pharm. Sin. B, 2018, 8, 137.

22 G. Hong, S. Diao, A. L. Antaris and H. Dai, Chem. Rev., 2015, 115, 10816.

23 S.-B. W. Kai Han, L. Qi, J.-Y. Zhu and X.-Z. Zhang, ACS Nano, 2015, 9, 10268.

24 L. Feng, S. Gai, Y. Dai, F. He, C. Sun, P. Yang, R. Lv, N. Niu, G. An and J. Lin, Chem. Mater., 2018, 30, 526.

25 J. Xu, W. Han, P. Yang, T. Jia, S. Dong, H. Bi, A. Gulzar, D. Yang, S. Gai, F. He, J. Lin and C. Li, Adv. Funct. Mater., 2018, 28, 1803804.

26 L. Feng, R. Xie, C. Wang, S. Gai, F. He, D. Yang, P. Yang and J. Lin, ACS Nano, 2018, 12, 11000.

27 Z. Hou, Y. Zhang, K. Deng, Y. Chen, X. Li, X. Deng, Z. Cheng, H. Lian, C. Li and J. Lin, ACS Nano, 2015, 9, 2584.

28 W. Sun, Y. Wen, R. Thiramanas, M. Chen, J. Han, N. Gong, M. Wagner, S. Jiang, M. S. Meijer, S. Bonnet, H. J. Butt, V. Mailänder, X. Liang and S. Wu, Adv. Funct. Mater., 2018, 28, 1804227.

29 M. K. Wolpert, J. R. Althaus and D. G. Johns, J. Pharmacol. Exp. Ther., 1973, 185, 202.
30 R. B. Elmes, Chem. Commun., 2016, 52, 8935.

31 Y. Li, Y. Sun, J. Li, Q. Su, W. Yuan, Y. Dai, C. Han, Q. Wang, W. Feng and F. Li, J. Am. Chem. Soc., 2015, 137, 6407.

32 R. H. Wong, T. Kwong, K. H. Yau and H. Y. Au-Yeung, Chem. Commun., 2015, 51, 4440.

33 Z. Li, X. He, Z. Wang, R. Yang, W. Shi and H. Ma, Biosens. Bioelectron., 2015, 63, 112.

34 A. Chevalier, Y. Zhang, O. M. Khdour, J. B. Kaye and S. M. Hecht, J. Am. Chem. Soc., 2016, 138, 12009.

35 F. Song, R. Liang, J. Deng, Z. Liu and X. Peng, Chin. Chem. Lett., 2017, 28, 1997.

36 J. Atchison, S. Kamila, H. Nesbitt, K. A. Logan, D. M. Nicholas, C. Fowley, J. Davis, B. Callan, A. P. McHale and J. F. Callan, Chem. Commun., 2017, 53, 2009.

37 X. Li, N. Zhao, L. Yu and Y.-A. Son, Mol. Cryst. Liq. Cryst., 2015, 608, 273.

38 L. Yuan, W. Lin, S. Zhao, W. Gao, B. Chen, L. He and S. Zhu, J. Am. Chem. Soc., 2012, 134, 13510.

39 Z. Xu and L. Xu, Chem. Commun., 2016, 52, 1094.

40 N. K. Roopa, V. Bhalla and M. Kumar, Chem. Commun., 2015, 51, 15614.

41 L. Yousif, K. Stewart and S. Kelley, ChemBioChem, 2009, 10, 1939.

42 D. Kessel and Y. Luo, Cell Death Differ., 1999, 6, 28.

43 H. Huang, S. Long, M. Li, F. Gao, J. Du, J. Fan and X. Peng, Dyes Pigm., 2018, 149, 633. 